\title{
Development of student entrepreneurial competence using the resources of social partnership
}

\author{
Tatiana Sergeeva ${ }^{1 *}$, Marina Podbolotova ${ }^{1}$, Ekaterina Natyrova $^{2}$, Svetlana Averianova ${ }^{3}$, and \\ Ilya Lobanov ${ }^{4}$ \\ ${ }^{1}$ Moscow City University, Directorate of Educational Programs, Moscow, Russia \\ ${ }^{2}$ Kalmyk State University named after B.B. Gorodovikov, Department of Mathematics, Informatics \\ and Teaching Methods, Elista, Russia \\ ${ }^{3}$ Russian Foreign Trade Academy, English Language Chair, Moscow, Russia \\ ${ }^{4}$ Institute of Education Development Strategy of the Russian Academy of Education, Laboratory of \\ Social and Humanitarian General Education, Moscow, Russia
}

\begin{abstract}
The paper brings to the fore the need for developing entrepreneurial competences in school students. It describes the concept of entrepreneurial competence as an ability to put forward original ideas and innovate along with communication, organisation, project management, action planning, and risk-taking competences, receptivity, and also knowledge and skills required for starting a new business and implementing practical ideas to proceed successfully. The case is made for developing courses in entrepreneurship and the criteria of efficiency are determined as follows: clearly set objectives, balanced theoretical and practical content, focus on learning by doing, voluntary approach and motivation, social partnership involving businessmen, financial institutions, and municipal government bodies, openness of the educational environment, availability of training for teachers and contacts with businessmen, and opportunity to present the outcomes. A description is provided of the model and algorithm of creating a school business incubator using the resources of social partnership with businessmen, financial institutions, and municipal governance bodies. The outcomes in entrepreneurship education in the context of a business incubator include the defence of a business project under the supervision of a mentor conducted in a competitive form in two stages, namely, the defence of the business idea and the project itself. Various procedures are used to assess business incubator performance, such as questionnaires for students, teachers, and mentors and expert assessment of students' entrepreneurial competence acquisition levels by teachers and mentors.
\end{abstract}

Keywords: entrepreneurship, competences, partnership, business incubator.

\footnotetext{
* Corresponding author: cirr1@mail.ru
} 


\section{Introduction}

Entrepreneurial competences are the key elements of any national economy. In many countries, they are part of the national curriculum for all age groups. Recommendations to include disciplines on entrepreneurship in the curriculum can be found in the papers of the Organisation for Economic Cooperation and Development.

Entrepreneurial competence is determined as a combination of an individual's abilities, personal qualities, and skills contributing to successful entrepreneurship. Entrepreneurial competence integrates the ability to generate original ideas and innovate, communication, organisation, project management, action planning, and risk-taking competences, receptivity, and also knowledge and skills required for starting a new business and implementing practical ideas to proceed successfully [1-3].

Entrepreneurial competences are developed with the attainment of knowledge, skills, and expertise, i.e., in the process of entrepreneurship education. The term "entrepreneurship education" is often understood too narrowly as a business and education associated with the acquisition of economic knowledge. This approach is not completely justified, as the ability to implement one's ideas is integral in nearly any type of professional activity. Accordingly, the objective of education is to develop all personal qualities, characteristics, and skills pertaining to entrepreneurial competences. However, in reality, except for a small number of educational organisations, Russian schools have not largely committed efforts to developing entrepreneurial competences. Teachers lack competence and knowledge or their knowledge is purely theoretical. As a result, even as entrepreneurship programmes emerge, the emphasis is on theoretical knowledge, not entrepreneurial skills. No professional retraining programmes are available for teachers. Moreover, schools do not maintain ties with local entrepreneurs. Most of the time entrepreneurship education takes the form of a small chapter in financial literacy programmes, which have become rather common in Russian schools [4-8].

Entrepreneurial competences combine creativity, initiative, problem-solving skills, resource management, and financial and technical knowledge. These competences help entrepreneurs and their staff drive change and adapt. They can be developed through entrepreneurship education and professional training aimed to encourage entrepreneurial thinking and behaviour. Schools, professional and higher education institutions develop these competences in students by building up their curriculum to accommodate special courses or independent modules in entrepreneurship.

\section{Methods}

Action research was chosen as research design, which implies collaboration between the researcher and the student; expert assessment was used as the method for model verification.

\section{Results and discussion}

It was established following a review of the literature and Russian and foreign practices [917] that entrepreneurship education should be viewed not as a separate course but as a consistent effort to build up the mix of qualities, competences, and specific thinking patterns. The following criteria will determine the efficiency of the development of entrepreneurial competences. 
1. The entrepreneurship education programme clearly sets objectives in the development of entrepreneurial competences and includes appropriate measurable performance criteria.

2. The programme balances theoretical and practical content, and the process of studies emphasises learning by doing.

3. Students are motivated and engage in the study process on their initiative and bear responsibility for their education.

4. The educational institution maintains external ties with companies, experienced businessmen, and the local community. Businessmen are actively engaged in the study process as mentors and consultants.

5. The programme creates an open educational environment and taps the resource base of social partners. Students participate in educational tours and internships at companies and firms.

6 Teachers have received special training in teaching entrepreneurship and using modern study aids and technologies. Formats are in place to facilitate teachers' interaction with businessmen for making adjustments in study programmes.

7. Students present their achievements and projects at various competition-based events with the participation of a wide network of experts.

Based on the conducted analysis, a model of a business incubator was developed in line with the above requirements. A business incubator is a community set at an educational institution and engaging students, teachers, businessmen, financial institutions, and other stakeholders seeking to develop students' entrepreneurial competences. The developed model of a business incubator was tested for schools of the Ruzsky and Leninsky districts of the Moscow region. More than 50 students aged 15-17 participated in the business incubator supported by seven organisations as social partners, including a bank, the chamber of commerce and industry, businesses, and a non-profit organisation.

The sequence of business incubator development included the following steps:

1. Determining the network of potential partners (businesses and other organisations) to support the development of entrepreneurial competence in school students and set up occupational guidance initiatives.

2. Engaging social partners for joint preparation of the main lines of work (projects, programmes, internships, etc.) for developing students' entrepreneurial competences based on occupational guidance input and stage of studies.

3. Working out questionnaires for students and other stakeholders (psychologists, tutors, parents) to measure interest in occupational initiatives developed jointly with social partners.

4. Working out retraining plans for teachers (seminars, webinars) with the support of social partners for developing students' entrepreneurial competences and setting up occupational guidance initiatives.

5. Building an action plan for developing entrepreneurial competences and setting up occupational guidance initiatives.

The functioning of a business incubator is governed by a bylaw and cooperation agreements with social partners. A bylaw on business project competitions was also prepared.

Students' activities at the business incubator included the completion of a special course under the guidance of mentors and organisations of social partners and the defence of business projects.

The course developed with input from social partners includes the attainment of both theoretical and practical knowledge via such forms of engagement as lectures, masterclasses, trainings, business games, workshops, educational tours, and internships. The course programme included parts concerning the fundamentals of entrepreneurship and 
commerce, business plan development, new business idea generation, and general aspects of financial literacy.

Studies took place both in school and at the grounds of partner organisations where tours and internships were arranged. In the end, students developed business projects and defended them in competition either individually or in groups.

Each project engaged the support of teachers from educational institutions and mentors from social partners, who provided advice and expertise on the developed materials.

The selection of students to the school business incubator was conducted voluntarily, and the main requirement was motivation to entrepreneurship. Students then attended classes under the course programme, worked on the business idea, and met potential mentors. Each student could engage more than one mentor if advice was needed in several areas, e. g., financials, entrepreneurship, legal support, etc.

The directions of business projects developed by students took into account territorial socioeconomic aspects in the area of the educational institution. E. g., in a rural school, students developed and implemented a project of agricultural production in the school yard. In the industrial district, the projects concerned the production of memorabilia, pastime initiatives, various personal services, etc.

The competition of projects developed by students was conducted in two stages. At the first stage, students defended their business ideas, which helped them further determine the optimum conditions of their implementation.

At the second stage, students defended their projects as a whole after preliminary expertise. A jury was formed, including businessmen, bankers, and municipal government officials uninvolved with the school business incubator. During the public defence, students presented their projects and answered the questions of the jury. The winners were awarded placements at major companies.

\section{Conclusion}

Each student had a portfolio tracking the results of the completion of the main chapters of the course, business ideas, the record of internships and placements, and the sequence of project development stages. The portfolio was filed by both teachers and mentors and the students themselves. Its content provided visibility into the student's progress in the attainment of entrepreneurial competences, their interests, preferences, and shortfalls. Assessments of activities (completion of the course, development of the business idea, and creation of the business project) were measured on a scale. The maximum total would be 100 points distributed as follows: completion of the course -30 points, business idea -20 points, business project development -30 points, and defence -20 points. Apart from that, various procedures were used to assess business incubator performance, specifically questionnaires for children, teachers, and mentors and expert assessment of students' entrepreneurial competence acquisition levels by teachers and mentors. Assessment results showed a significant improvement of students' entrepreneurial motivation, their willingness to put forward original ideas and to implement them, which is a crucial condition for an accomplished social life and future occupation.

\section{References}

1. L.A. Trusova, Sovremennye problemy nauki i obrazovaniya, 2, 145 (2012)

2. I. Komarkova, D. Gagliardi, J. Conrads, A. Collado, Entrepreneurship Competence: An Overview of Existing Concepts, Policies and Initiatives. Final Report (Publications Office of the European Union, Luxembourg, 2015) 
3. C.S. Mishra, R.K. Zachary, Strategic Entrepreneurship Journal, 1, 11-26 (2014)

4. T.F. Sergeeva, M.I. Podbolotova, V.A. Kalnei, Novoe pokolenie vybiraet finansovuyu gramotnost [New generation opts for financial literacy] (Ileksa, Moscow, 2019)

5. E.P. Konstantinova, Psikhologo-ekonomicheskie issledovaniya, 3, 94-107 (2016)

6. O. Kuzina, Voprosy ekonomiki, 8, 129-148 (2015)

7. E.G. Rubtsov, Mezhdunarodnyi zhurnal eksperimentalnogo obrazovaniya, 3, 255-256 (2015)

8. D.V. Moiseeva, Finansovaya gramotnost naseleniya Rossiiskogo regiona: ekonomikosotsiologicheskii analiz [Financial literacy of population in a Russian region: economic and social analysis]. Thesis (Volgograd State Technical University, Volgograd, 2017)

9. T. Patrikova, Spravochnik zamestitelya direktora shkoly, 1, 58-69 (2017)

10. A.V. Liubanenko, Regionalnye problemy preobrazovaniya ekonomiki, 5(91), 43-48 (2018)

11. I.I. Diakov, D.V. Mukhina, et al., Sovremennoe obrazovanie, 4, 19-31 (2018)

12. T.A. Potenko, Mir nauki. Pedagogika i psikhologiya, 6, 1-9 (2018)

13. L.I. Gareeva, Sovremennaya vysshaya shkola: innovatsionnyi aspekt, 3(41), 85-94 (2018)

14. S.I. Naumov, L.V. Konstantinova, Vysshee obrazovanie v Rossii, 3, 137-146 (2019)

15. V.A. Malinin, Vestnik Nizhegorodskogo universiteta imeni N.I. Lobachevskogo. Sotsialnye nauki, 1(53), 125-131 (2019)

16. B. Akbosh, Acquiring Business Skills as a Teenager (2018). Accessed on: December 16, 2020. [Online]. Available: https://www.risepreneur.com/business-skills-to-learn-asa-teenager/

17. European Commission, 3.8 Development of entrepreneurship competence (EACEA National Policies Platform, Brussels, 2019). Accessed on: December 16, 2020.

[Online]. Available: https://eacea.ec.europa.eu/nationalpolicies/en/content/youthwiki/38-development-entrepreneurship-competence-belgiumflemish-community 